\title{
Clifford Thompson
}

\section{Tell Me How Long the Train's Been Gone}

In the mid-1980s, in my early twenties, I moved to New York City with the aim of-yawn-being a writer. Astonishingly, I had read very little of the work of James Baldwin, important reading for anyone who wants to write and essential for an aspiring writer who is black. In college I had read a couple of his stories and an essay or two, enough for me to delude myself that I "knew" his work, but all of it together didn't add up to a whole book. Then, in 1988, an editor at Bantam Doubleday Dell, where I then worked as an editorial assistant, gave me the Dell paperback editions of eleven of Baldwin's books. The gift changed my life.

I have read writers I thought were as good as Baldwin at spinning images and metaphors, and Baldwin has many betters when it comes to tightness of plotting; but I am no longer in my twenties, and I have yet to encounter Baldwin's equal at creating a sense of intimacy with the reader. This quality lends his rage at injustice, and his calls for love and understanding, a particular urgency. I have heard it argued that Baldwin was a better essayist than fiction writer, which I do not necessarily dispute; but I do contend that the sense of intimacy is present in the best of his fiction, and nowhere more so than in the 1968 work I judge to be one of his best novels, Tell Me How Long the Train's Been Gone.

There is a great deal of dissent on that point. In early 1998, when the Library of America published a two-volume set of selected works by Baldwin, edited by Toni Morrison, reviewers in the New York Times Book Review, the New Yorker, and the Times Literary Supplement took the occasion to dismiss the later books of James Baldwin as the work of an embittered writer who had lost his artistic and intellectual integrity, and who, when he deigned to work, used fiction and nonfiction as twin megaphones through which to scream "racist" in white America's face. Hilton Als in the New Yorker deemed it "merciful" that the volume containing the novels omitted the latter three and included only Go Tell it on the Mountain, Another Country, and many people's favorite, Giovanni's Room, which-coincidentally or not-is the single Baldwin novel with no black characters. Perhaps the omission of Train from this list is the result of an attempt to draw a line neatly separating the two Baldwins-a 
line that these reviewers place at about 1964. In truth, the line mostly holds. I leave it to Baldwin aficionados more loyal (or less discriminating) than myself to defend the comparatively thin If Beale Street Could Talk or the bloated, pretentious Just Above My Head. (Another writer publishing the latter book, my editor-friend at Bantam Doubleday Dell quipped, "would have been sued for plagiarizing Baldwin's earlier books.") But life rarely cooperates with our attempts to form neat categories. While I agree with widely held beliefs about much of Baldwin's later work, I stand behind the solid, moving Tell Me How Long the Train's Been Gone.

The novel's narrator is Leo Proudhammer, a famous black American movie and stage actor who, at age thirty-nine, looks back on his life. The catalyst for this reflection is the heart attack that has interrupted both his real life and the performance he is giving-two things that are, so the novel contends, often one and the same, for Leo and for all of us, particularly us Americans. Leo spends his childhood in the 1930s and 1940s in a series of cramped Harlem apartments with his West Indian father, his southern-born mother, and his older brother, Caleb. Leo's father is an embittered man, having left a land of little opportunity for one of little more, and one drenched in racism, to boot. Ironically, his intense pride in his African heritage, because it fails to translate into respect from his white landlord and creditors, makes him a pitiable figure in Leo's eyes. The person Leo looks up to is Caleb, seven years his senior, a worldly figure respected and feared among his (Caleb's) friends, who at the same time despise the shrimpy and sissified Leo.

One of the major themes in all of Baldwin's work is the failure of Americans to love one another, to take on the risks which that entails. Leo is an illustration of these risks and of the consequences of not accepting them. What Leo feels for his parents, particularly his father, makes him either unable or unwilling to love them as he should: "If we had been on the island which had been witness to his birth instead of the unspeakable island of Manhattan, he felt, and I also eventually began to feel, that it would not have been so hard for us all to trust and love each other," Leo says, adding later, "But it is ... hard to love the beaten. It means accepting their condition; whereas, precisely, one is asking oneself, What shall I do to be saved?" The price Leo pays for this failure to love is detachment from the very people who anchor him to the world.

But Leo loves Caleb, and he pays for this, too, losing his brother not once but twice. The first time is when Caleb's friends rob a store and wound the 
manager; Caleb's connection to the crime is not clear, but he is sent, at seventeen, to a prison work farm in the Deep South. He returns home at twenty-one, hardened on the outside but suffering at his core. In the bed he shares with Leo, now fourteen, he bares his soul, relating the horrors he experienced in prison; Leo now takes on the role of older brother, comforting Caleb; the comfort is physical as well as emotional, and the brothers more or less make love. What would be an act between two sideshow freaks in the hands of a lesser writer becomes, through Baldwin's (hence our) insights into Leo, an understandable, moving, even inevitable communion between brothers who care deeply for each other:

I held my brother very close, I kissed him and caressed him and I felt a pain and wonder I had never felt before. My brother's heart was broken; I knew it from his touch. In all the great, vast, dirty world, he trusted the love of one person only, his brother, his brother, who was in his arms. And I thought, Yes. Yes. Yes. I'll love you, Caleb, I'll love you forever. ...

Leo's second loss comes when Caleb finds himself unable to stomach the indignities that are the black working man's lot in the early 1940s; lasting less than a day on the job his father has lined up for him, he leaves New York. Leo, perhaps trying to compensate for the loss of emotional love through its physical manifestations, perhaps simply no longer caring what happens to him, becomes a (bi)sexual creature of the streets.

Enter Barbara King. In some ways as arrogant as the white, racist, moneyed family she left behind in Kentucky, young Barbara is also large-hearted and open to human experience in all its forms; thus her taking up residence with nineteen-year-old Leo and a couple of others on "two floors in a falling-down tenement on the East Side" of Manhattan. Leo, Barbara, and their friends, "filthier than gypsies, more abject than beggars, [their] mouths open obscenely for the worm, the morsel, the crumb, which the world never drop[s]," keep body and soul together by working as artists' models and by stealing food.

Barbara aspires to be an actress. Acting has also been Leo's aim all along. In a country where, as Baldwin maintains, people are afraid to learn about each other for fear of what they might find out about themselves, the ultimate 
symbol - of both a desirable remoteness and the masking of one's true selfis the actor. Leo senses this even as a preteen hanging out in movie theaters: "I looked at the stills from the show, seeing people in attitudes of danger, in attitudes of love, in attitudes of sorrow and loss. They were not like any people I had ever seen and this made them, irrevocably, better." On one level, Leo has already been an actor. To survive on the streets, Leo adopts the persona of someone whom it is unwise to mess with: his "ruthlessness" masks a

paradoxical and very real helplessness, and it covered my terrible need to lie down, to breathe deep, to weep long and loud, to be held in human arms, almost any human arms, to hide my face in any human breast, to tell it all, to let it out, to be brought into the world, and, out of human affection, to be born again.

The consequence of this posing cuts to the heart of the book: "I found myself imprisoned in the stronghold I had built. The day came when I wished to break my silence and found that I could not speak: the actor could no longer be distinguished from his role."

Barbara finagles an invitation to an uptown party where many theater types will be present, and she takes Leo along. This is how they meet the married couple who run a prestigious theater workshop in New Jersey, where Leo and Barbara become summer apprentices.

Barbara eventually becomes Leo's lover, in the process also becoming the yang to Caleb's yin. Where Caleb, a black male, is Leo's sibling turned (briefly) lover, Barbara, a white female, is Leo's lover turned sibling: because Leo and Barbara are bound by their love for each other but ultimately cannot commit to each other romantically, their relationship becomes like that between brother and sister-Leo even speaks of their "incestuous" relationship and of kissing Barbara "like a brother." The Caleb/Barbara yin-yang relation extends to the manner in which love falls short. Caleb leaves Leo, and the break is irreparable; when next Leo sees him, Caleb has found religion, and has begun preaching the word of a God Leo cannot bring himself to worship; the brothers now regard each other across a great divide. But it is Leo who pulls back from Barbara. In part, he finds the stress of an interracial relationship in the 1940 s more than he can, or wants to, bear: 
Some guys jumped me one night when I was coming home from the theater, blacking both eyes, and bloodying my nose. We sometimes sat in our house in the evening as though we were waiting for the mob to come and carry us away. . . I was simply, ignobly, and abjectly afraid. I didn't like the taste of my own blood. I didn't want all my teeth knocked out, didn't want my nose smashed, my eyes blinded, didn't want my skull caved in. ... .

And, in part, Leo pulls away out of fear of being left himself. Barbara's "eminence," he says, was

but a matter of time. And what could she then do with her sad, dark lover, a boy trapped in the wrong time, the wrong place, and with the wrong ambitions trapped in the wrong skin?. . The most subtle and perhaps the most deadly of alienations is that which is produced by the fear of being alienated.

It is often said-but is no less true for that-that he who cannot love himself cannot love someone else. Shortly following the last passage, speaking of the "fear of being alienated," Leo says, "This fear obscured a great many fears, but it obscured, above all, the question of whether or not I wished to be committed to Barbara, or to anyone else, and it hid the question of whether or not I was capable of commitment." And why is Leo perhaps not capable of commitment? He shows signs of not valuing himself, at least not sufficiently. As Leo tells it, "Everyone wishes to be loved, but, in the event, nearly no one can bear it. Everyone desires love but also finds it impossible to believe that he deserves it. ... [O]ne does many things, turns the key in the lock over and over again, hoping to be locked out."

But Leo ultimately demonstrates acceptance of love from another, and love for himself, not only at the same time but through the same act: his falling in love with "Black" Christopher, who, in addition to being a fully realized character in his own right, is also in many ways a re-creation of Leo at a younger age. Among other things, Christopher is tough, proud, hungry, vulnerable, bisexual, and possessed of a grand ambition but no clear plan for realizing it. Christopher-Christ-has taken on Leo's human attributes; to continue that analogy, Christopher offers love, and Leo saves his own soul by accepting it. For Leo, embracing Christopher means stepping out of his "role," 
acknowledging and embracing both the attractive and unattractive aspects of his own self. This, Baldwin suggests, is the key to the crucial ability to love other people.

Recent critical writings would lead one to believe that the post-1964 Baldwin viewed American society in the crudest possible terms: white equals evil, allcontrolling oppressor, black equals noble, helpless oppressed. To read Tell Me How Long the Train's Been Gone is to be disabused of this notion. (Unless one believes, as some critics seem to, that the very mention of race in a novel constitutes preaching - and a lack of genuine artistry-on the part of the author.) Train is not a naturalistic novel, in which societal forces dictate everything about a character, down to the color of his socks. To be sure, Leo lives in an unfair world; society frowns on his romance with Barbara to the point of physically punishing him for it. But Leo has choices, and his choices reveal his strengths and weaknesses-his humanity. Leo chooses not to accept the conditions of being with Barbara, and this shrinking from the challenge of love is one of the things for which he takes years to forgive himself: one of the obstacles to his self-love.

Far from being crude, Baldwin's grasp of the ramifications of the racial situation in America as evidenced in Train is quite sophisticated. It is displayed particularly well in one scene that is worth the price of the book. In the New Jersey town where they are theater apprentices, Leo and Barbara eat at a Sicilian-owned restaurant with Madeleine, an older, white actress, and Jerry, their fellow worker and Barbara's lover (prior to her involvement with Leo). Jerry is Italian-American; he and the restaurant owner establish an instant rapport and banter with each other in Italian. Leo envies the ease with which Jerry interacts with his cultural kinsman, the way he is able to be a citizen of America-as evidenced by his being in the company of Madeleine, Barbara, and Leo-and at the same time retain his "otherness." For Leo finds that his cultural currency with other blacks in the town is void in the presence of whites, since that currency, unlike that shared by Jerry and the Sicilians, is founded largely on negativity, on the distrust/fear of whites. The inadequacy of distrust/fear as a cultural foundation is underscored when two black men walk into the restaurant:

Here I was, sitting with three white people-or, rather, with two white women. I could not leave my table and go to theirs. They could not leave their table and come to ours-or, rather, in this 
context, mine. We could not do what we wished to do, which was simply to be easy with each other. No: there we sat, under the eyes of the observant and bewildered Sicilians, studiously ignoring each other. ... For a moment, I hated all of my companions, for whom, as I supposed, nothing had happened.

But again, Leo has choices. Rising above the awkwardness of the situation, "making a certain resolution," Leo asks a waiter to take drinks over to the two black men, who eventually come to Leo's table and enjoy a pleasant exchange with Leo, Barbara, Jerry, and Madeleine.

Finally, some may take issue with a certain meandering quality, a seeming plotlessness, in this novel. But I would argue, on the one hand, that Train is no more lacking in plot than Another Country, and on the other, that the absence of a ruthlessly driven narrative saves Train from the melodrama that, for this reader, slightly mars the climax of Giovanni's Room. What, then, keeps the reader turning the pages? To discuss this is to return to the subject near the beginning of this essay, to Baldwin's gift for intimacy. Baldwin makes us care about Leo and want to know what happens to him, and he accomplishes this by creating in his narrator-contrary to recent pronouncements-a fleshand-blood character who transcends the confines and dictates of race. 